\title{
Marta Gałązka
}

\section{Uniwersytet Kardynała Stefana Wyszyńskiego w Warszawie}

\section{Procedury głosowania stosowane w wybranych krajach europejskich.}

Od lat obserwuje się wzrastajace zainteresowanie tak zwanymi „alternatywnymi procedurami głosowania"1. Wymienia się wśród nich przede wszystkim: głosowanie przez pełnomocnika, głosowanie korespondencyjne, głosowanie elektroniczne i głosowanie przy wykorzystaniu, tak zwanej „mobilnej urny wyborczej”. Upatruje się w nich narzędzie wzmacniające realizację zasady powszechności wyborów, niwelujące bariery organizacyjne, utrudniające udział w głosowaniu.

W artykule zostana omówione poszczególne alternatywne procedury głosowania. W pierwszej części, zostanie zaprezentowana procedura głosowania przez pełnomocnika, w drugiej - głosowanie korespondencyjne, w trzeciej - głosowanie elektroniczne i w ostatniej - głosowanie przy pomocy mobilnej urny wyborczej.

Procedura głosowania przez pełnomocnika, jest instytucja pozwalajaca wyborcy, który z różnych przyczyn nie jest w stanie udać się do lokalu wyborczego i zagłosować osobiście, udzielić upoważnienia innemu wyborcy do oddania głosu w jego imieniu². Wiąże się ona z zaufaniem do osoby głosującej w imieniu wyborcy. Budzi jednak wiele zastrzeżeń natury konstytucyjnej, przede wszystkim, co do zgodności z zasadami bezpośredniości i równości wyborów3. Podczas prac nad zmiana ordynacji wyborczej do Sejmu Rzeczypospolitej Polskiej i do Senatu Rzeczypospolitej Polskiej, Krajowa Rada Sadownictwa wskazała, że instytucja głosowania przez pełnomocnika, budzi watpliwości, co do zgodności

\footnotetext{
${ }^{1}$ Alternatywnymi do tradycyjnego głosowania osobiście w lokalu wyborczym.

2 J. Zbieranek, Nowe procedury: głosowanie korespondencyjne i przez pełnomocnika, [w:] K. Skotnicki (red.), Kodeks wyborczy. Wstępna ocena, Warszawa 2011, s. 41.

3 Wiele uwag dotyczących głosowania przez pełnomocnika zostało zawartych w artykule: A. Rakowska, Głosowanie przez pełnomocnika (uwagi krytyczne), „Studia wyborcze”, tom IV 2007, s. 65-77.
} 


\section{Marta Gałązka}

z bezpośredniością wyborów, gdyż stanowi to formę wyborów pośrednich, w których rzeczywistą decyzję wyborczą podejmuje pełnomocnik4. W Polsce procedura głosowania przez pełnomocnika została zaskarżona także do Trybunału Konstytucyjnego przez posłów na Sejm, Prawa i Sprawiedliwości. Ich uwagi dotyczyły tego, że głosowanie przez pełnomocnika narusza zasadę bezpośredniości wyborów, jest sprzeczne z równością praw wyborczych (zasada równości wyborów w znaczeniu formalnym) oraz narusza art. 2 Konstytucji. Ostatni zarzut nie został jednak należycie uzasadniony. Trybunał Konstytucyjny w wyroku z dnia 20 lipca 2011 rok u orzekł, że zarzuty wnioskodawców są bezpodstawne. Stwierdził, że pełnomocnik oddaje głos w imieniu wyborcy, a nie w swoim imieniu, czyli nie jest to naruszenie zasady równości w znaczeniu formalnym. W orzeczeniu Trybunału podkreślono, że wnioskodawca nie doprecyzował standardów wywodzonych z art. 2 Konstytucji, które w jego mniemaniu narusza instytucja głosowania przez pełnomocnika oraz nie wskazał elementów, które są niewystarczające w kwestii wymogów konstytucyjnych5. W opinii Trybunału, bezpośredniość wyborów nie obejmuje wymogu głosowania osobistego, więc zasada ta nie jest w tym przypadku naruszana. Natomiast w Austrii, gdzie głosowanie osobiste jest zasadą konstytucyjną ${ }^{6}$, głosowanie przez pełnomocnika nie jest dozwolone.

Komisja Wenecka dopuszcza instytucję głosowania przez pełnomocnika. Uznała, że głosowanie przez pełnomocnika dozwolone jest tylko wtedy, jeśli podlega ścistym przepisom [...]. Liczba pełnomocnictw posiadanych przez jednego wyborcę musi być ograniczona?.

Procedura głosowania przez pełnomocnika stosowana jest między innymi we Francji, Holandii, Wielkiej Brytanii, Belgii czy też Szwecjï.

W Belgii, gdzie istnieje obowiązek udziału w wyborach, z procedury głosowania przez pełnomocnika, moga korzystać osoby, które z powodu choroby lub utraty sił, z powodów zawodowych, przekonań religijnych, pozbawione wolności

\footnotetext{
4 Opinia Krajowej Rady Sądownictwa z dnia 16 maja 2007 r. W przedmiocie projektu ustawy o zmianie ustawy - Ordynacja wyborcza do Sejmu Rzeczypospolitej Polskiej i do Senatu Rzeczypospolitej Polskiej, www.krs.pl/main2.php? search=opinia, data dostępu 2.03.2013.

5 Wyrok Trybunału Konstytucyjnego z dnia 20 lipca 2011 r., Sygn. Akt. K 9/11, s. 38-49.

${ }^{6}$ Art. 26 Bundes-Verfassungsgesetz.

${ }^{7}$ Code of good practices in electoral matters. Guidelines and explanatory report. Adopted by the Venice Commission at its 52nd session (Venice, 18 - 19 October, 2002). Opinion no 190/2002, s. 23. Treść dostępna pod adresem: www.venice.coe.int/docs/2002/CDL-AD(2002)023-e.pdf.

8 A. Sokala, Głosowanie przez pełnomocnika, [w:] B. Michalak, A. Sokala (red.), Leksykon prawa wyborczego i systemów wyborczych, Warszawa 2010, s. 42.
} 
bądź przebywające w szkole lub za granica, nie mogą samodzielnie udać się do lokalu wyborczego. Wszystkie te sytuacje muszą być potwierdzone odpowiednimi zaświadczeniami?.

W Wielkiej Brytanii procedura głosowania przez pełnomocnika skierowana jest do osób, które z powodu choroby, wykonywania służbowych obowiazków, przebywania na wakacjach, uczestniczenia w zajęciach edukacyjnych bądź przebywania za granica, nie sa w stanie udać się do lokalu wyborczego. Aby móc skorzystać z tej procedury, należy wypełnić formularz i odesłać go do lokalnego biura rejestracji wyborców na sześć dni przed dniem wyborów ${ }^{10}$. W przypadku zagrożenia stanu zdrowia oraz na podstawie stosownego zaświadczenia lekarskiego, wniosek o głosowanie przez pełnomocnika, może zostać złożony w dniu wyborów do godziny 17:0011. Pełnomocnik musi posiadać prawo wyborcze i może przyjać pełnomocnictwo maksymalnie od dwóch osób12.

W Szwecji także istnieje ograniczenie, co do kręgu osób mogących korzystać z głosowania przez pełnomocnika. Dostęp do tej metody mają osoby chore, starsze i niepełnosprawne. Pełnomocnikiem może być każda osoba wskazana przez wyborcę uprawnionego do głosowania ${ }^{13}$. Na terenach wiejskich, gdzie odległości do lokali wyborczych są znaczne, osobą, która głosuje w imieniu innego wyborcy może być nawet listonosz ${ }^{14}$.

Szeroki katalog wyborców, którzy moga korzystać z głosowania przez pełnomocnika występuje we Francji. Procedura ta została wprowadzona już w 1975 roku, na miejsce głosowania korespondencyjnego (ze względu na częste występowanie oszustw wyborczych). W ten sposób moga głosować wszyscy wyborcy, którzy w dniu wyborów nie są w stanie sami udać się do lokalu wyborczego. Podczas wyborów parlamentarnych w 2012 roku, procedura zgłaszania chęci głosowania przez pełnomocnika, była znacznie uproszczona i przystępniejsza dla wybor-

\footnotetext{
9 Stemming bij volmacht, www.ibz.rrn.fgov.be/index.php?id=1662\&L=1, data dostępu 19.11.2012.

10 Voting by proxy, www.aboutmyvote.co.uk/how_do_i_vote/voting_by_proxy.aspx, data dostępu 19.11.2012.

11 United Kingdom of Great Britain and Northern Ireland. General Election, 6 May 2010. OSCE/ODIHR Election Assessment Mission Report, s. 12.

12 Voting by proxy, www.aboutmyvote.co.uk/how_do_i_vote/voting_by_proxy.aspx, data dostępu 19.11.2012.

13 Vallag (2005:837), www.riksdagen.se/sv/Dokument-Lagar/Lagar/Svenskforfattningssamling/ Vallag2005837_sfs-2005-837/, data dostępu 23.02.2013.

14 K. Dośpiał-Borysiak, P. Kowalski, Szwedzki system wyborczy - ramy instytucjonalne i polityczne, „Studia wyborcze”, Tom IV, Łódź 2007, s. 88.
} 
ców, gdyż nie musieli oni udowadniać, że rzeczywiście nie są w stanie samodzielnie stawić się w lokalu wyborczym. Wiele partii politycznych oferowało pomoc w załatwieniu formalności związanych z tą procedura, a nawet deklarowały znalezienie osoby, która mogłaby oddać w ich imieniu głos. Taka praktyka wzbudziła duże zaniepokojenie między innymi OBWE, która podkreśliła, że organizacja wyborów wymaga podjęcia działań gwarantujących równość i tajność wyborów, a także pozwalająca wyborcom dokonać samodzielnych wyborów ${ }^{15}$.

W Holandii także istnieje liberalne ustawodawstwo związane z tą procedura. Każdy obywatel, który nie jest w stanie zagłosować osobiście, może bez podania przyczyny skorzystać z możliwości głosowania przez pełnomocnika. Co ciekawe, osoby pozbawione wolności, swój głos mogą oddać jedynie przez pełnomocnika. Wyborca może przyjąć maksymalnie dwa pełnomocnictwa ${ }^{16}$.

W Polsce procedura głosowania przez pełnomocnika była najdłużej rozpatrywana procedurą w czasie prac legislacyjnych. Miała ona szansę znaleźć się w polskim prawie wyborczym już w 1992 roku17. Po raz pierwszy wyborcy mogli z niej skorzystać podczas wyborów prezydenckich, a następnie wyborów samorzadowych w 2010 roku. Piątego stycznia 2011 roku, uchwalono Kodeks wyborczy, który uchylił poprzednie ustawy oraz wprowadził wiele udogodnień, w tym również możliwość głosowania przez pełnomocnika ${ }^{18}$. Z procedury moga skorzystać wyborcy o znacznym lub umiarkowanym stopniu niepełnosprawności oraz ci, którzy najpóźniej w dniu głosowania ukończyli 75 lat. Pełnomocnictwa można udzielić osobie, która wpisana jest do rejestru wyborców w tej samej gminie, co udzielający pełnomocnictwa albo osoba, która posiada zaświadczenie o prawie do głosowania. Pełnomocnictwo można przyjąć od jednej osoby z wyjątkiem sytuacji, gdy osobą udzielającą pełnomocnictwa jest wstępna, zstępna, małżonek (małżonka), brat, siostra bądź osoba pozostająca w stosunku przysposobienia, opieki lub kurateli w stosunku do pełnomocnika. Wtedy to możliwe jest przyjęcie pełnomocnictwa od dwóch osób. Do głosowania w imieniu niepełnosprawnego wyborcy, nie można upoważnić osoby, która wchodzi w skład komisji obwodowej właściwej dla obwodu głosowania

\footnotetext{
15 Republic of France. Parliamentary Elections, 10 and 17 June 2012. OSCE/ODIHR Election Assessment Mission Final Report, s. 6-7.

16 The Netherlands. Early Parliamentary Elections, 12 September 2012. OSCE/ODIHR Election Assessment Mission Report, s. 6.

17 K. Skotnicki, Zasada powszechności..., op. cit., s. 271.

18 Szerzej o pracach nad wprowadzeniem do polskiego prawa wyborczego procedur głosowania przez pełnomocnika: J. Zbieranek, Alternatywne procedury głosowania w..., op. cit., s. 109-111.
} 
osoby udzielającej pełnomocnictwa do głosowania, a także mężów zaufania, jak również kandydatów w danych wyborach. Akt pełnomocnictwa sporządzany jest na podstawie wniosku wyborcy, który powinien być wniesiony do wójta gminy, w której wyborca wpisany jest do rejestru wyborców. Wniosek, który zawiera podstawowe dane wyborcy i pełnomocnika powinien być złożony najpóźniej na 10 dni przed dniem wyborów ${ }^{19}$. W pierwszej turze wyborów prezydenckich, przez pełnomocnika głosowało 6456 osób20. W drugiej turze z tej możliwości skorzystało 11613 osób21. W 2011 roku w wyborach do Sejmu przez pełnomocnika głosowało 12427 osób22, a w wyborach do Senatu 12394 osób23.

Procedura głosowania korespondencyjnego to instytucja polegająca na tym, że wyborca, który wyrazi w prawem przewidzianej formie wolę skorzystania z tego sposobu głosowania, otrzymuje od organu wyborczego przesyłkę wyborcza, która zawiera kartę lub karty do głosowania, odpowiednie koperty i - w zależności od kraju - inne niezbędne dokumenty. Wyborca wypełnione dokumenty odsyła droga pocztową na adres właściwego organu wyborczego24. Ta procedura nie budzi tak wielu watpliwości odnośnie zgodności z zasadami konstytucyjnymi, jak głosowanie przez pełnomocnika. Pewne zastrzeżenia zwiazane są z możliwością nieprzestrzegania zasady tajności w momencie wypełniania przez wyborcę karty do głosowania oraz podczas dostarczania jej do komisji wyborczej25. Zasada tajności może być jednak w pełni zachowana poprzez utworzenie skutecznych narzędzi ochrony aktu głosowania oraz przesyłek zawierających kartę bądź karty do głosowania. Komisja Wenecka uważa, że głosowanie korespondencyjne może być sto-

\footnotetext{
19 Ustawa z dnia 5 stycznia 2011 r. - Kodeks wyborczy (Dz. U. z dnia 31 stycznia 2011 r. nr 21, poz. 112).

20 Obwieszczenie Państwowej Komisji Wyborczej z dnia 21 czerwca 2010 o wynikach głosowania i wyniku wyborów Prezydenta Rzeczypospolitej Polskiej, zarządzonych na dzień 20 czerwca 2010 r., www.prezydent2010.pkw.gov.pl/ALL/pliki/DOKUMENTY/komunikaty/ObwieszczeniePOL.pdf, data dostępu 16.05.2012.

21 Obwieszczenie Państwowej Komisji Wyborczej z dnia 5 lipca 2010 r. o wynikach ponownego głosowania i wyniku wyborów Prezydenta Rzeczypospolitej Polskiej, www.prezydent2010.pkw.gov.pl/ALL/ pliki/DOKUMENTY/komunikaty/ObwieszczeniePOL_2.pdf, data dostępu 16.05.2012.

22 Obwieszczenie Państwowej Komisji Wyborczej z dnia 11 października 2011 r. o wynikach wyborów do Sejmu Rzeczypospolitej Polskiej przeprowadzonych w dniu 9 października 2011 r. (Dz. U. nr 218, poz. 1294).

23 Obwieszczenie Państwowej Komisji Wyborczej z dnia 11 października 2011 r. o wynikach wyborów do Senatu Rzeczypospolitej Polskiej przeprowadzonych w dniu 9 października 2011 r. (Dz. U. nr 218, poz. 1295).

${ }_{24}$ A. Sokala, Głosowanie korespondencyjne, [w:] B. Michalak, A. Sokala (red.), op. cit., s. 41-42.

${ }^{25}$ M. Gapski, Nowe techniki..., art. cyt., s. 85.
} 
sowane w przypadku, gdy usługi pocztowe w danym kraju są wolne i bezpieczne oraz sprawnie funkcjonuja. Należy też wprowadzić mechanizmy, dzięki którym możliwe będzie uniknięcie oszustw wyborczych oraz innych nadużyć26.

Procedura głosowania korespondencyjnego wykorzystywana jest w Holandii, Norwegii, Hiszpanii, Słowacji, Wielkiej Brytanii, Niemczech, Szwajcarii, Szwecji, Słowacji i w Polsce27. Między innymi na Słowacji, w Szwecji, Estonii, Holandii z głosowania korespondencyjnego mogą korzystać osoby stale lub czasowo przebywające za granica.

W Holandii z możliwości głosowania korespondencyjnego mogą korzystać osoby, które przebywają za granica. Wyborcy muszą nie później niż na sześć tygodni przed wyborami, wystosować wniosek do burmistrza Hagi - administracyjnej stolicy Holandii. Obywatele, którzy podobny wniosek składali przed poprzednimi wyborami, automatycznie otrzymuja pakiet do głosowania. Karty do głosowania muszą być odesłane najpóźniej do godziny 15:00 w dniu wyborów28.

Estońskie prawo wyborcze przewiduje między innymi, możliwość głosowania korespondencyjnego w wyborach parlamentarnych, europejskich oraz w referendach. Estończyk przebywający za granica, który chce zagłosować korespondencyjnie, wskazuje okręg wyborczy, w którym ma być oddany jego głos (na podstawie wcześniejszego miejsca zamieszkania na terenie Estonii, bądź miejsca zamieszkania rodziców, bądź innych przodków). Chęć skorzystania z tej metody powinna być zgłoszona do 30 dnia przed dniem wyborów. W tym celu należy złożyć do placówki dyplomatycznej wniosek z załączoną kopią dowodu osobistego. Placówka dyplomatyczna przesyła obywatelowi kartę wyborczą, instrukcję głosowania, listę kandydatów oraz dwie koperty. Wyborca po wypełnieniu karty do głosowania, umieszcza ją w mniejszej kopercie, która natomiast powinna się znaleźć w większej (zewnętrznej). Należy tam napisać swoje imię, nazwisko, numer identyfikacyjny oraz numer okręgu wyborczego. Przy polu „głosowanie za granica” należy również postawić krzyżyk. Przesyłka, której koszt wysłania ponosi wyborca, powinna zostać dostarczona do placówki dyplomatycznej29.

\footnotetext{
26 Code of good practices in electoral matters. Guidelines and explanatory report. Adopted by the Venice Commission at its 52 ${ }^{\text {nd }}$ session (Venice, 18 - 19 October, 2002). Opinion no 190/2002, s. 23. Treść dostępna pod adresem: www.venice.coe.int/docs/2002/CDL-AD(2002)023-e.pdf. ${ }_{27}$ A. Sokala, Głosowanie korespondencyjne, [w:] B. Michalak, A. Sokala (red.), op. cit.

28 The Netherlands. Early Parliamentary Elections, 12 September 2012. OSCE/ODIHR Election Assessment Mission Report, s. 7.

29 Riigikogu Election Act (RT I 2002, 57, 355), chapter 7, § 47.
} 
Na Słowacji, prawo do głosowania korespondencyjnego przysługuje tym wyborcom, którzy mają miejsce stałego pobytu na Słowacji, ale w dniu wyborów przebywaja poza terytorium kraju oraz obywateli Słowacji, którzy nie posiadaja miejsca stałego pobytu na terytorium Słowacji30. Należy jeszcze podkreślić, że jest to jedyna możliwość oddania głosu w wyborach parlamentarnych przez osoby przebywające poza krajem ${ }^{31}$. Po raz pierwszy Słowacy mogli głosować w ten sposób, podczas wyborów parlamentarnych w 2006 roku32. Na 50 dni przed wyborami osoby, które mają miejsce stałego pobytu na terytorium Słowacji muszą złożyć wniosek o możliwość głosowania za pośrednictwem poczty w gminnym urzędzie miejsca swojego stałego pobytu. Natomiast ci, którzy nie posiadają miejsca stałego pobytu na Słowacji, wniosek dostarczają do dzielnicy Bratysława-Petržalka33. Gmina na 35 dni przed wyborami, wysyła wyborcy materiały do głosowania. Są one umieszczane w nieprześwitującej kopercie o wymiarach i kolorze używanym przez komisję wyborczą i opatrzoną pieczęcią urzędową gminy. W przesyłce znajdują się karty do głosowania, koperty oraz wskazówki dotyczące sposobu oddania głosu. Wyborca na karcie do głosowania wskazuje za pomoca cyfr, któremu z maksymalnie czterech kandydatów daje pierwszeństwo swojego głosu. Po zagłosowaniu, wyborca wkłada kartę do głosowania do koperty zwrotnej i odsyła ją na swój koszt. Przesyłka musi dotrzeć do gminy najpóźniej w ostatnim dniu roboczym przed dniem wyborów 34 .

W Niemczech w ten sposób moga głosować osoby, którym ważny powód uniemożliwił obecność w ich okręgu wyborczym w dniu wyborów, przeprowadziły się i nie zostały ujęte w spisie wyborców w nowym miejscu zamieszkania, lub którym przyczyny zawodowe, czy też osobiste uniemożliwiaja przybycie do lokalu wyborczego 35 . Procedura głosowania korespondencyjnego cieszy się niesłabnąca

\footnotetext{
30333 Zákon z 13 mája 2004 o vol'bách do Národnej rady Slovenskiej Republiky, (Z. z. č 333/2004).

31 Proces volieb zo zahraničia je zložity, hlasovat' sadá len poštou, „Hospodárske Noviny” (06.03.2010r.), www.hnonline.sk/slovensko/c1-40930570-proces-volieb-zo-zahranicia-je-zlozityhlasovat-sa-da-len-postou, data dostępu 7.10.11.

32 L. Cebulka, L. Trellová, Wybory w Republice Słowackiej - alternatywne sposoby głosowania, „Studia Wyborcze", 2009, t. 8 s. 73.

33333 Zákon z 13 mája 2004 o vol'bách do Národnej rady Slovenskiej Republiky, (Z. z. č 333/2004).

34333 Zákon z 13 mája 2004 o vol'bách do Národnej rady Slovenskiej Republiky, (Z. z. č 333/2004).

35 A. Krasnowolski, Głosowanie przez pełnomocnika, głosowanie antycypowane i głosowanie korespondencyjne w krajach europejskich i Kanadzie, Warszawa 2006, s. 26.
} 
popularnością. W 1957 roku drogą korespondencyjną oddano 4,9\% głosów, w 1983 roku już 10,5\%, a w 2005 roku 18,6\%36.

W Polsce po wejściu w życie „Kodeksu wyborczego”, korespondencyjnie moga głosować osoby przebywające w dniu wyborów za granicą oraz osoby niepełnosprawne. Wyborca przebywający za granica, chęć głosowania korespondencyjnego musi zgłosić konsulowi do 15 dnia przed dniem wyborów. Można to zrobić ustnie, pisemnie, telegraficznie, poprzez telefaks lub w formie elektronicznej37. Zamiar głosowania korespondencyjnego przez osoby niepełnosprawne winien być zgłoszony wójtowi do 21 dnia przed dniem wyborów. Zgłoszenie może być dokonane ustnie, pisemnie, telefaksem lub w formie elektronicznej38.

W Polsce po wpisaniu przez konsula wyborcy przebywającego za granica, wysyła on nie później niż do 10 dnia przed dniem wyborów, wyborca otrzymuje od konsula pakiet wyborczy, który zawiera zaadresowana kopertę zwrotna, kartę (lub karty) do głosowania, kopertę na kartę (lub karty) do głosowania, oświadczenie o osobistym i tajnym oddaniu głosu na karcie do głosowania oraz instrukcje głosowania. Koperty zwrotne, które trafią do konsulatu, przesyłane są do właściwej obwodowej komisji wyborczej. Koperty na kartę do głosowania wyjęte z kopert zwrotnych wrzucane są do urny wyborczej.

Do osób niepełnosprawnych pakiet wyborczy właściwy urząd gminy wysyła wyborcy nie później niż 7 dni przed dniem wyborów. Musi on być dostarczony wyłącznie do rąk własnych wyborcy, po okazaniu dokumentu potwierdzającego tożsamość i pisemnym pokwitowaniu odbioru. W skład pakietu wyborczego wchodzi: koperta zwrotna, karta lub karty do głosowania, koperta na kartę lub karty do głosowania, instrukcja głosowania korespondencyjnego, oświadczenie o osobistym i tajnym oddaniu głosu na karcie do głosowania oraz - jeśli wyborca ich zażądał nakładki na karty do głosowania w alfabecie Braille’a. Koperta zawierająca pakiet wyborczy oraz koperta zwrotna oznaczone są napisem „przesyłka wyborcza”39.

${ }^{36}$ A. Żukowski, Głosowanie korespondencyjne - wskazówki dla Polski, „Studia wyborcze” t. VII, Łódź 2009, s. 28.

37 Ustawa z dnia 5 stycznia 2011 r. - Kodeks wyborczy (Dz. U. z dnia 31 stycznia 2011 r. nr 21, poz. 112).

38 Ustawa z dnia 5 stycznia 2011 r. - Kodeks wyborczy (Dz. U. z dnia 31 stycznia 2011 r., nr 21, poz. 112).

39 Ustawa z dnia 5 stycznia 2011 r. - Kodeks wyborczy (Dz. U. z dnia 31 stycznia 2011 r., nr 21, poz. 112). 
W wyborach parlamentarnych w 2011 roku, pakiety wyborcze zostały wysłane do 22951 osób. Z urn w wyborach do Sejmu wyjęto 17161 kart z kopert na karty do głosowania, a w wyborach do Senatu - 17016 kart40.

W Wielkiej Brytanii ta procedura głosowania znana jest już od 1918 roku41. Jednak wtedy kragg osób mogacych z niej korzystać był bardzo wąski. Od 2000 roku każdy obywatel Wielkiej Brytanii, może na żądanie zagłosować drogą korespondencyjna. Wraz z poszerzeniem katalogu wyborców mogących korzystać z tego mechanizmu, wzrosło ryzyko występowania nadużyć. Podczas wyborów lokalnych w 2004 roku doszło do fałszerstw wyborczych na masową skalę, co doprowadziło do unieważnienia wyborów w dwóch okręgach wyborczych w Birmingham. Sprawiło to, że na nowo rozpoczęto debatę na temat bezpieczeństwa tej procedury. Coraz częściej podnoszono, że należy ją zlikwidować. Podpisany wniosek o głosowanie drogą korespondencyjną musi być złożony do 11 dnia przed dniem głosowania. Wyborca otrzymuje przed wyborami tak zwany zestaw z kartą do głosowania (kartę do głosowania, kopertę na kartę do głosowania, oświadczenie bezpieczeństwa, kopertę zwrotną na kartę do głosowania). Komisja, po otrzymaniu wypełnionych dokumentów, sprawdza je i wrzuca do urny wyborczej42.

Hiszpańskie prawo wyborcze przewiduje możliwość głosowania korespondencyjnego, zarówno dla wyborców zamieszkałych na terenie kraju jak i stale, bądź czasowo przebywających za granica. Co ciekawe, osoba, która składała wniosek o możliwość skorzystania z tej procedury, nie może zmienić zdania i zagłosować osobiście. Wyborca przebywający w Hiszpanii, który chce oddać swój głos korespondencyjnie, może to zrobić bez podawania uzasadnienia43.

W niektórych państwach istnieje możliwość głosowania w urzędzie pocztowym. Pracownicy poczty są przeszkalani przez urzędników wyborczych. Na poczcie wydzielane jest specjalne pomieszczenie, gdzie wyborca może oddać swój głos, zgodnie z zasadą tajności. Taką procedurę przewidują między innymi ustawo-

40 Obwieszczenie PKW z dnia 11 października 2011 r. o wynikach wyborów do Sejmu Rzeczypospolitej Polskiej przeprowadzonych w dniu 9 października 2011 r. (Dz. U. Nr 218, poz. 1294) oraz Obwieszczenie PKW z dnia 11 października 2011 r. o wynikach wyborów do Senatu Rzeczypospolitej Polskiej przeprowadzonych w dniu 9 października 2011 r. (Dz. U. Nr 218, poz. 1295).

${ }^{41}$ A. Żukowski, op. cit.

42 K. Skotnicki, Rejestr wyborców i głosowanie korespondencyjne w Wielkiej Brytanii, [w:] J. Zbieranek (red.), Prawo wyborcze. Analizy. Interpretacje. Rekomendacje, Warszawa 2009, s. 56-61.

43 Spain. Early Parliamentary Elections, 20 November 2011. OSCE/ODIHR Election Assessment Mission Final Report, s. 20. 
dawstwa wyborcze Estonii i Litwy. Na Litwie głosowanie na poczcie odbywa się w godzinach pracy urzędu od piątego dnia przed dniem wyborów44.

Głosowanie elektroniczne obejmuje użycie technologii elektronicznych w procedurach zwiazanych z wyborami, a przynajmniej podczas aktu oddawania głosu45. Mianem głosowania elektronicznego obejmuje się kilka technik: głosowanie za pomoca maszyny elektronicznej w lokalu wyborczym, głosowanie przy użyciu kiosków internetowych umieszczonych w miejscach publicznych, głosowanie z zastosowaniem komputera osobistego podłączonego do Internetu, a także głosowanie za pomocą telefonu komórkowego bąź interaktywnej telewizjit6. Cechami głosowania elektronicznego są nowoczesność, efektywność i łatwość w obsłudze. Jest ono jednocześnie kosztowne, skomplikowane technologicznie oraz wymaga stosowania specjalnych środków zapewniajacych bezpieczeństwo procesu głosowania. International Institute for Democracy and Electoral Assistance (IDEA) zaprezentował szereg wytycznych, które powinny być uwzględnione podczas projektowania i wdrażania głosowania elektronicznego w danym państwie. IDEA rekomenduje między innymi, aby przed wprowadzeniem tej procedury, zwrócić uwagę na doświadczenia innych państw, które mogą się okazać bardzo pomocne. Organizacja zaleca także zapewnienie przejrzystej kontroli i bezpieczeństwa, przygotowanie kompleksowego programu szkoleń dla członków komisji wyborczych oraz edukacji wyborców dotyczących korzystania z tej procedury47.

Za prekursora głosowania elektronicznego w Europie uznaje się Estonię. Propozycja wprowadzenia tej procedury głosowania pojawiła się już w 2001 roku. Głównym motywem wdrożenia tej metody głosowania było zwiększenie zainteresowania młodych ludzi udziałem w głosowaniu oraz zwiększenie wygody udziału w wyborach. W 2002 roku estoński parlament przyjał ustawę wprowadzająca głosowanie elektroniczne na terenie całego kraju, w wyborach parlamentarnych w 2005 roku. Niektóre ugrupowania - Partia Centrum oraz Unia Ludowa Estonii były sceptyczne co do wprowadzenia tej procedury. Watpliwości miał także Prezy-

\footnotetext{
${ }^{44}$ A. Żukowski, op. cit., s. 27.

45 Factsheet. Electronic voting - The first real practice, [w:] B. Kaufmann, R. Buchi, N. Braum (red.), Guidebook to direct democracy. In Switzerland and beyond, Marburg 2010, s. 130.

46 Materiały seminaryjne przygotowane na spotkanie „Głosowanie elektroniczne w Polsce?”, organizowane przez Instytut Spraw Publicznych 3 lipca 2007 roku, Treść dostępna pod adresem: www.isp.org.pl/files/8885853860086913001184933460.pdf, data dostępu 23.03.12.

47Zob. Introducing Electronic Voting: Essential Considerations, Policy Paper, IDEA, Sztokholm 2011, s. 28-29.
} 
dent Estonii, który postanowił nie podpisywać ustawy nowelizującej samorządową ustawę wyborczą (uchwalona 28 czerwca 2005 roku), a skierować ją do Izby Kontroli Konstytucyjności Sądu Najwyższego. Obawa dotyczyła przede wszystkim tego, że osoby głosujące za pośrednictwem Internetu mają możliwość zmiany swojego głosu. Nie dotyczy to osób, które głosują w sposób tradycyjny. Zdaniem polityków narusza to równość wyborów ${ }^{48}$. Trybunał uznał, że ponieważ wszyscy wyborcy mają możliwość głosowania elektronicznego, to nie narusza równości wyborów. W opinii Sądu możliwość ponownego zagłosowania ma zmniejszyć ryzyko wpływania na wyborców do zagłosowania w określony sposób i jest to niezbędny gwarant dla tajności głosowania elektronicznego49.

Estonia była jednym z pierwszych państw, w których podjęto działania, w celu wprowadzenia głosowania za pośrednictwem Internetu. Miała ku temu sprzyjające warunki. Estonia, określana często „E-stonia”, od wielu lat zajmuje wiodąca pozycje w zastosowaniu technologii elektronicznych w sektorze publicznym i prywatnym50.

Podstawą identyfikacji wyborców, którzy chcą głosować elektronicznie jest dowód osobisty wyposażony w kartę chipową. Po rozpoznaniu wyborcy, następuje uwierzytelnienie za pomocą kodu PIN. Wyborca oddaje swój głos, który jest szyfrowany (tak zwana koperta wewnętrzna) i potwierdza swój głos podpisem cyfrowym (tak zwana koperta zewnętrzna). Wyborca otrzymuje potwierdzenie przyjęcia głosu $^{51}$. Informacje te przesyłane są do centralnego systemu, a następnie rozdzielane - dane osoby głosującej służą do tego, aby oznaczyć, że oddała już swój głos, a głos trafia do liczenia52. Głosowanie odbywa się na stronie internetowej Państwowej Komisji Wyborczej między 6 a 4 dniem przed dniem wyborów. W przypadku gdy wyborca oddaje swój głos jeszcze raz, poprzedni głos zostaje anulowany. Istnieje również możliwość odwołania głosu oddanego elektronicznie poprzez tradycyjne

48 Republic of Estonia. Parliamentary Elections 4 March 2007. OSCE/ODIHR Election Assessment Mission Report, Warsaw 2007, s. 12-13.

49 Zob. Judgment of Constitutional Review Chamber of The Supreme Court (3-4-1-13-05), www.nc.ee/?id=381, data dostępu 27.05.2012.

50 Report for the Council of Europe. Internet voting in the March 2007 Parliamentary Elections in Estonia, (31.07.2007 r.), www.vvk.ee/public/dok/Coe_and_NEC_Report_E-voting_2007.pdf, data dostępu 28.06.2012.

51 Report for the Council of Europe. Internet voting in the March 2007 Parliamentary Elections in Estonia, (31.07.2007 r.), www.vvk.ee/public/dok/Coe_and_NEC_Report_E-voting_2007.pdf, data dostępu 28.06.2012.

52 D. Mider, Głosowanie przez Internet a demokracja, „Studia Politologiczne”, t. 20, Warszawa 2011, art., cyt., s. 50. 
głosowanie w dzień wyborów w lokalu wyborczym, ale tylko do godziny 17:00. Wtedy to elektronicznie oddany głos zostaje usunięty53.

Misja obserwacyjna OBWE w 2007 roku uznała, że urzędnicy wyborczy w pełni przejrzyście wdrożyli system głosowania elektronicznego i w jak największym stopniu starano się zapewnić bezpieczeństwo przebiegu głosowania. Zauważono, że choć możliwość głosowania elektronicznego zwiększa możliwość udziału w głosowaniu wszystkim obywatelom, to jednocześnie pojawia się ryzyko ataków z zewnątrz lub wewnętrznych problemów. Dostrzeżono także, że choć Krajowa Komisja Wyborcza podjęła znaczne wysiłki na rzecz zminimalizowania ryzyka, to nie pojawiła się żadna kontrola ze strony partii politycznych i społeczeństwa obywatelskiego ${ }^{54}$.

Prace nad wprowadzeniem głosowania elektronicznego prowadzone sa w wielu krajach europejskich. Poza Estonia, najbardziej zaawansowane w tej kwestii są Szwajcaria i Belgia.

W Szwajcarii głosowanie elektroniczne odbywa się tylko w niektórych kantonach. Pierwsze głosowanie miało miejsce w 2003 roku. Genewa, a następnie Zurych jako pierwsze rozpoczęły projekty dotyczące głosowania elektronicznego. Przed rozpoczęciem wyborów, wynajęci hakerzy dokonują próby złamania systemu55. Obecnie z nowej możliwości oddawania głosu, korzystają już mieszkańcy trzynastu kantonów.

W Belgii od początku lat 90 . XX wieku, prowadzone są próby wdrożenia głosowania za pomocą głosomatów56. Bardzo często jednak podczas oddawania głosów, pojawia się wiele problemów technicznych.

Mobilna urna wyborcza wykorzystywana jest głównie przez osoby niepełnosprawne, przewlekle chore, które mają znaczne problemy z poruszaniem się. Osoby te odpowiednio wcześnie zgłaszają we właściwej komisji wyborczej chęć skorzystania z mobilnej urny wyborczej57. Z niewielką, przenośną urną wyborczą oraz kartami do głosowania udaje się do wyborcy kilku członków komisji wyborczej.

53 K.W. Czaplicki, Alternatywne sposoby głosowania (Zarys problemów), [w:] S. Grabowska, R. Grabowski (red.), Międzynarodowa Konferencja Naukowa „Alternatywne sposoby głosowania a aktywizacja elektoratu", Rzeszów 2007, s. 37-38.

${ }^{54}$ Republic of Estonia. Parliamentary elections 4 March 2007. OSCE/ODIHR Election Assessment Mission Report, Warsaw 2007, s. 4-5.

55 D. Mider, Głosowanie przez Internet a demokracja, „Studia Politologiczne”, t. 20, Warszawa 2011, s. 233.

56 Ibidem, s. 227.

57 Termin w poszczególnych krajach ustalany jest ustawowo. 
Obywatel po wypełnieniu karty do głosowania wrzuca ją do przenośnej urny ${ }^{58}$. Wykorzystanie mobilnej urny wyborczej jest procedurą budząca największy sprzeciw ekspertów. Wskazuje się tu na organizacyjne oraz techniczne trudności komisji wyborczych, w celu zapewnienia bezpieczeństwa wyborom. Komisja Wenecka nie rekomenduje tej procedury głosowania: „Stosowanie mobilnych urn wyborczych nie jest wskazane, gdyż towarzyszy temu poważne ryzyko oszustw"59. Procedura ta wykorzystywana jest między innymi na Słowacji, w Estonii, Ukrainie.

Słowacy mieszkający w kraju moga korzystać z mobilnej urny wyborczej. Prawo do głosowania z jej użyciem przysługuje wyborcom, którym stan zdrowia nie pozwala na głosowanie w lokalu wyborczym. W tym celu moga oni złożyć odpowiedni wniosek. Komisja wyborcza wysyła do wyborcy co najmniej dwóch swoich członków. Mają oni ze sobą przenośną urnę wyborczą i są zobligowani do zachowania takich warunków, aby tajność głosowania była przestrzegana60. Podczas wyborów samorządowych dochodzi jednak do nieprawidłowości i kupowania głosów. Zdarza się również, że przenośne urny wyborcze obsługują osoby nieuprawnione do tego. Jest to powodem do składania protestów wyborczych ${ }^{61}$.

Część obywateli Estonii, którzy nie są w stanie głosować w lokalu wyborczym w dniu wyborów, moga oddać swój głos w domu za pomocą mobilnej urny wyborczej. Wyborca musi złożyć wniosek do urzędu gminy na dzień przed wyborami lub w dniu wyborów do godziny 16:00. Trzeba w nim podać powód, dla którego obywatel chce głosować w domu. Uzasadnionymi trudnościami są zły stan zdrowia, zaawansowany wiek, trudne warunki drogowe lub brak transportu. W przypadku gdy wniosek zostanie sklasyfikowany jako bezzasadny, wyborca jest informowany 0 przyczynie odmowy głosowania w domu. Po pozytywnym rozpatrzeniu wniosku, do mieszkania wyborcy przychodzi dwóch urzędników wyborczych. Obywatel podpisuje się na liście wyborców głosujących w domu, a następnie otrzymuje kartę do głosowania, którą wypełnia i wrzuca do urny62.

\footnotetext{
58 J. Zbieranek, Alternatywne procedury głosowania w Polsce na tle państw Unii Europejskiej, „Studia BAS" 2011, nr 3, s. 98.

59 Code of good practices in electoral matters. Guidelines and explanatory report. Adopted by the Venice Commission at its 52nd session (Venice, 18 - 19 October, 2002). Opinion no 190/2002, s. 23. Treść dostępna pod adresem: www.venice.coe.int/docs/2002/CDL-AD(2002)023-e.pdf. 60333 Zákon z 13 mája 2004 o vol'bách do Národnej rady Slovenskiej Republiky, §30.

61 L. Orosz, Volebnesüdnictwo na Slovensku, „Roczniki administracji i prawa”, www.62.29.131.140/czasopisma/Documents/Roczniki_administracji_Rok_XI.pdf, data dostępu 12.06.2012.

62 Riigikogu Election Act (RT I 2002, 57, 355), chapter 7, § 46.
} 
Warto zauważyć, że zmniejsza się liczba osób korzystających z mobilnej urny wyborczej. W wyborach parlamentarnych w 1999 roku w ten sposób swój głos oddało 14834 osób i w każdych kolejnych wyborach liczba systematycznie spadała. W 2011 do mobilnej urny wyborczej swój głos oddało 7648 Estończyków63.

Alternatywne procedury głosowania cieszą się rosnącą popularnością. Zazwyczaj kierowane są do wąskich grup obywateli - głównie osób niepełnosprawnych, starszych czy też przebywających za granica. Nieliczne państwa adresuja je do wszystkich obywateli. Stosowanie alternatywnych procedur głosowania w znaczący sposób wzmacnia realizację zasady powszechności wyborów. Dzieje się tak przede wszystkim w tych krajach, w których katalog osób uprawnionych do korzystania z nich, jest szeroki. Jednocześnie pojawia się tam najwięcej zagrożeń związanych z naruszeniami pozostałych zasad wyborczych - głównie zasady tajności oraz zasady równości wyborów. Istotny jest więc monitoring stosowania innych niż tradycyjne procedur głosowania oraz wypracowanie najbardziej dogodnych dla wyborców mechanizmów korzystania z nich, a jednocześnie bezpiecznych i wolnych od nadużyć. Pomocne w tej kwestii są bez watpienia doświadczenia innych państw, a także wszelkie rekomendacje Biura Instytucji Demokratycznych i Praw Człowieka Organizacji Bezpieczeństwa i Współpracy w Europie, Komisji Weneckiej czy też innych organizacji zajmujących się kwestiami wyborczymi.

${ }^{63}$ A. Heinsalu, A. Koitmāe, M. Pilving, P. Vinkel, Elections in Estonia 1992-2011, Tallinn 2012, s. 10. 